\title{
IONIC COMPOSITION OF ENDOLYMPH IN TELEOSTS: ORIGIN AND IMPORTANCE OF ENDOLYMPH ALKALINITY
}

\author{
P. PAYAN ${ }^{1}$, H. KOSSMANN ${ }^{2}$, A. WATRIN ${ }^{3}$, N. MAYER-GOSTAN ${ }^{3}$ AND G. BOEUF $^{2}$ \\ ${ }^{1}$ Laboratoire de Physiologie Environnementale, Faculté des Sciences, Université de Nice-Sophia Antipolis, \\ BP 71, 06108 Nice CX2, France, ${ }^{2}$ Laboratoire de Physiologie des Poissons, IFREMER, Centre de Brest, \\ BP 70, 29280 Plouzané, France and ${ }^{3}$ Laboratoire de Physiologie Cellulaire et Moléculaire des Epithéliums et des \\ Compartiments Calciques, URA CNRS 1938, Faculté des Sciences, Université de Nice-Sophia Antipolis, \\ BP 71, 06108 Nice CX2, France
}

Accepted 26 March 1997

\begin{abstract}
Summary
Ionic $\left(\mathrm{Na}^{+}, \mathrm{K}^{+}, \mathrm{Cl}^{-}, \mathrm{PO}_{4}{ }^{3-}, \mathrm{pH}\right)$, total $\mathrm{CO}_{2}$, total calcium and protein concentrations in the plasma and endolymph of the inner ear were compared in trout Oncorhynchus mykiss and turbot Scophthalmus maximus. In both species, saccular endolymph was characterized by high levels of $\mathrm{K}^{+}$ and total $\mathrm{CO}_{2}$ and in trout by an alkaline $\mathrm{pH}$. The kinetic characteristics of proton secretion across the saccular epithelium of trout were investigated using a titration

sensitive $\mathrm{Na}^{+} / \mathrm{K}^{+}$exchangers. Proton secretion was partially inhibited by acetazolamide and completely inhibited in $\mathrm{Na}^{+}$-free Ringer or in the presence of $1 \mathrm{mmoll}^{-1}$ amiloride. A cellular model stressing the importance of proton exchange through the saccular epithelium is proposed to explain the regulation of endolymph $\mathrm{pH}$, a crucial factor for the deposition of otolith calcium.
\end{abstract} technique in which isolated saccules were mounted as closed sacs. The rate of proton secretion depends strongly on the pH of the Ringer's solution and secretion stops at a pH below 7.2. Proton secretion is driven by an energydependent mechanism involving basolateral ouabain-
Key words: teleost, inner ear, saccular epithelium, proton secretion, otolith, biocalcification, trout, Oncorhynchus mykiss, turbot, Scophthalmus maximus.

\section{Introduction}

The inner ear of teleosts differs from that of other vertebrates mainly in the complete absence of a cochlea. The membranous labyrinth consists of three connecting chambers, the utricule, saccule and lagena, each containing one otolith. These chambers are continuous with three semi-circular canals, and the entire labyrinth is filled with endolymph. This organ is involved in the maintenance of equilibrium and in the detection of gravity and sound (Dale, 1980; Lowenstein, 1971). In the fields of fisheries biology and management, the analysis of otolith microstructure is of prime importance. Fish otoliths are calcium carbonate concretions with annual and daily rhythmic depositions (Panella, 1971). Thus, in addition to their use in the estimation of age, otolith analysis has been used to obtain information about a fish's somatic growth history from back calculations of fish size (Campana and Neilson, 1985; Jones, 1992).

In higher vertebrates, the labyrinth fluid is always characterized by high $\mathrm{K}^{+}$and low $\mathrm{Na}^{+}$concentrations, showing a composition like that of intracellular fluid except for its $\mathrm{Ca}^{2+}$ content (total calcium $0.3-0.6 \mathrm{mmol}^{-1}$ with approximately
$10 \%$ in the ionized form). In fish, the otolith is in direct contact with the endolymph, and only a few studies have examined the composition of endolymph, mainly in the saccule, which is the largest chamber of the labyrinth in most species. By comparison with other vertebrates, fish endolymph shows a higher $\mathrm{Na}^{+}$concentration (110-140 $\mathrm{mmol}^{-1}$ : Enger, 1964; Fange et al. 1972; Kalish, 1991; Mugiya and Takahashi, 1985; Watanabe and Miyamoto, 1973) compared with 3-40 $\mathrm{mmol}^{-1}$ in mammals (Sterkers et al. 1988). A more surprising difference described by Mugiya and Takahashi (1985) is the relative alkalinity of the saccular endolymph (plasma 7.56; endolymph 8.06), whereas mammalian endolymph and plasma have the same pH (Sterkers et al. 1988).

In this paper, we re-examine the ionic composition $\left(\mathrm{Na}^{+}, \mathrm{K}^{+}\right.$, $\left.\mathrm{Cl}^{-}, \mathrm{Ca}^{2+}, \mathrm{PO}_{4}{ }^{3-}, \mathrm{pH}\right)$, total $\mathrm{CO}_{2}$ and protein contents of the saccular endolymph in a primitive freshwater teleost (trout) and a more highly evolved seawater teleost (turbot). We also analyze the kinetic characteristics of proton secretion using a titration technique in which an isolated saccule is mounted as a closed sac.

\footnotetext{
*e-mail: Girard@Unice.Fr
} 


\section{Materials and methods \\ Fish handling}

Approximately 80 trout [Oncorhynchus mykiss (Walbaum)], of about $200 \mathrm{~g}$ body mass, 12-13 months old, were supplied by a local fish farmer near Nice, France, and reared in running tap water at approximately $14{ }^{\circ} \mathrm{C}$ in circular tanks. Twenty turbot [Scophthalmus maximus (Raf. 1810)], of 100-150 g body mass and 7-8 months old, were obtained from IFREMER Brest, France, and kept in a closed seawater system maintained at $14{ }^{\circ} \mathrm{C}$. Both groups were fed every morning.

\section{Collection of plasma and endolymph}

A maximal amount of blood (4-5 ml) was quickly collected with a heparinized syringe by puncturing the caudal vessels. The $\mathrm{pH}$ was measured, then the blood sample was centrifuged and the separated plasma kept on ice until analysis. Immediately after blood sampling, the inner ear was exposed to allow collection of the endolymph sample $(6-7 \mu \mathrm{l})$. In both trout and turbot, the delay between blood and endolymph sampling was short (approximately $3 \mathrm{~min}$ ). The fish was killed by spinal transection, decapitated behind the gill and the head placed on ice. The skull was opened with a frontal incision just behind the eyes, and the saccular membrane was exposed after anterior displacement of the brain. The two species studied differ in the anatomical characteristics of the bony labyrinth and in the viscosity of the endolymph, necessitating different collecting procedures. In the turbot, the bone cavity containing the saccule has a narrow opening and the endolymph was sampled in situ. In order to minimize its contamination by blood, the operative field was rinsed five times with $1 \mathrm{ml}$ of ion-free medium (i.e. $300 \mathrm{mmol}^{-1}$ glycine treated with anionexchange resin; Chelex 100 and Biorad AG50WX8) and adjusted to $\mathrm{pH} 7.2$ with Tris. Before sampling, any fluid remaining in the brain cavity was removed with absorbent paper. Then, under a stereomicroscope, the tip of a calibrated capillary tube (CEI, GC100TF-10), fixed to a micromanipulator (Leitz), was inserted into the saccule and the endolymph slowly sucked up using an infusion and withdrawal syringe pump (Braun). In the trout, the lower parts of the membranous labyrinth were carefully excised after cutting the semicircular canals. The isolated labyrinth was then rinsed five times in ion-free medium and placed in a plastic cup. The surrounding liquid was removed with absorbent paper and the endolymph sampled as for the turbot.

\section{pH determination in blood and endolymph}

Blood $\mathrm{pH}$ was determined immediately after sampling. To determine the $\mathrm{pH}$ of trout endolymph, larger trout (weighing approximately $2 \mathrm{~kg}$ and approximately 2 years old) were used since their saccules are large enough to allow the complete insertion of the tip of a needle-like $\mathrm{pH}$ electrode (INC microelectrode, $\mathrm{MI} 407,0.8 \mathrm{~mm}$ in diameter) connected to a $\mathrm{pH}$ meter (Tacussel, TT processor 2) into the otosac, thus minimizing air contact and the escape of $\mathrm{CO}_{2} \cdot \mathrm{pH}$ values were recorded within $15 \mathrm{~s}$ of the incision being made in the saccule wall. To facilitate handling, the $\mathrm{pH}$ electrode was fixed on a micromanipulator (Leitz). Unfortunately, it was not possible to measure the endolymph $\mathrm{pH}$ of turbot since no large enough fish were available.

\section{Protein and ion determinations}

The volume of each sample was determined by measuring the length of endolymph in the calibrated capillary with a slide caliper. Although the volume obtained from an individual saccule was only a few microlitres, the use of a calibrated capillary tube made possible measurements of ionic $\left(\mathrm{Na}^{+}, \mathrm{K}^{+}\right.$, $\mathrm{Cl}^{-}$) and protein concentrations in an individual sample. However, for each $\mathrm{CO}_{2}, \mathrm{Ca}^{2+}$ or $\mathrm{PO}_{4}{ }^{3-}$ measurement, an entire sample was needed; thus, it was not possible to obtain data for all the variables from one saccule.

For the protein, $\mathrm{Cl}^{-}, \mathrm{Na}^{+}$and $\mathrm{K}^{+}$measurements, the entire endolymph sample was injected into $0.5 \mathrm{ml}$ of distilled water and the capillary tube was rinsed repeatedly by aspiration. For each determination of total calcium, total $\mathrm{CO}_{2}$ or $\mathrm{PO}_{4}{ }^{3-}$, a whole endolymph sample was injected directly into the measurement vial. $\mathrm{Na}^{+}$and $\mathrm{K}^{+}$were determined by flame photometry (Eppendorf) after appropriate dilutions. $\mathrm{Ca}^{2+}, \mathrm{Cl}^{-}$, $\mathrm{PO}_{4}{ }^{3-}$, total $\mathrm{CO}_{2}$ and protein were measured by spectrophotometry using Sigma kits for the first four and Commassie Blue for protein with bovine serum albumin as a standard.

\section{Determination of proton secretion by isolated trout saccules}

A ligature was placed at the base of the semicircular canals of a freshly excised labyrinth, and the saccule sac was immediately immersed in the titration vessel. The labyrinth was held in place by the thread of the ligature. The appearance of protons in the external medium was monitored by automatic titration with a Tacussel titrator (TT Processor 2) coupled to an autoburette Tacussel (EBX3). The $\mathrm{pH}$ was continuously recorded using a microelectrode. The solution bathing the labyrinth was $1 \mathrm{ml}$ of modified Ringer (see below), continuously agitated with a magnetic stirrer with renewed air at the surface. At the beginning of each period, the $\mathrm{pH}$ of the incubation medium was measured and entered as an end-point in the titration apparatus. The appearance of secreted protons was determined from the amount of titrant delivered into the titration vials by the autoburette, the delivery being recorded graphically, and the initial slope was used for calculations (see Results). Individual experiments included a first period which served systematically as its own control. Both saccules of an individual trout were studied; the second was kept in situ, bathed with an aerated Ringer's solution and excised just before use.

\section{Statistics}

Data are expressed as means \pm S.E.M. ( $N=$ number of experiments). Comparisons were analyzed using $t$-tests for paired or unpaired observations and one-way analysis of variance (ANOVA). Significance was attributed at $P<0.05$. 


\section{Chemicals}

The modified Ringer was composed of: $135 \mathrm{mmoll}^{-1} \mathrm{NaCl}$, $2.5 \mathrm{mmoll}^{-1} \mathrm{KCl}, 1 \mathrm{mmoll}^{-1} \mathrm{MgCl}_{2}, 1.5 \mathrm{mmoll}^{-1} \mathrm{NaH}_{2} \mathrm{PO}_{4}$, $0.4 \mathrm{mmoll}^{-1} \mathrm{KH}_{2} \mathrm{PO}_{4}, 1.5 \mathrm{mmol}^{-1} \mathrm{CaCl}_{2}$; buffered with either $1 \mathrm{mmoll}^{-1} \mathrm{NaHCO}_{3}$ or $1 \mathrm{mmoll}^{-1}$ Hepes. The solution also contained freshly added glucose $\left(1 \mathrm{gl}^{-1}\right)$ and was aerated before use. The $\mathrm{Na}^{+}$-free solution was obtained by replacing $\mathrm{NaCl}$ by an equivalent amount of choline chloride.

Pharmacological products (ouabain, amiloride, cyanide, acetazolamide) were purchased from Sigma.

\section{Results}

Ion and protein contents in plasma and endolymph

The endolymph volumes collected from individual saccules were $5.7 \pm 0.5 \mu \mathrm{l}(N=9)$ and $6.3 \pm 0.3 \mu \mathrm{l}(N=14)$ in trout and turbot, respectively. Ion contents measured in plasma and endolymph are presented in Table 1 . In both species, the endolymph composition differs markedly from that of the plasma, the most striking difference being that of $\mathrm{K}^{+}$content, with endolymph concentrations being 20 (turbot) to 41 (trout) times higher than those in plasma. The endolymph $\mathrm{Na}^{+}$ concentrations were approximately $50-70 \%$ of those in plasma, while the $\mathrm{Cl}^{-}$concentrations were not significantly different. The total calcium concentration was approximately $40-45 \%$ of that of plasma. Phosphate levels were 2-5 times lower in the endolymph than in the plasma.

Total endolymph protein concentrations in trout and turbot (Table 1) were approximately $2 \mathrm{gl}^{-1}$, well below the level measured in plasma (15 times less), but characteristic of the level in cephalic fluids.

In both fish species, the endolymph also differed from the plasma by having a significantly higher total $\mathrm{CO}_{2}$ concentration (2-3 times greater), with higher values in trout than in turbot. Experiments performed in large trout showed that $\mathrm{pH}$ in the endolymph was significantly more alkaline than in the plasma (Table 1).

Characteristics of proton secretion by isolated saccules

Preliminary experiments were conducted to determine the optimal buffer conditions for accurate measurement of secreted protons (concentrations from 0 to $10 \mathrm{mmol}^{-1}$ bicarbonate or Hepes were tested). It was found that $1 \mathrm{mmoll}^{-1}$ bicarbonate or Hepes was an appropriate concentration to maintain a stable external $\mathrm{pH}$ and was low enough to allow detection of small quantities of protons excreted by an isolated saccule. Thus, the titrant used was a $1 \mathrm{mmol}^{-1} \mathrm{NaOH}$ solution except in $\mathrm{Na}^{+}$-free experiments, in which $1 \mathrm{mmol}^{-1} \mathrm{KOH}$ was used.

Preliminary experiments showed that proton secretion by an isolated saccule could be followed for $1 \mathrm{~h}$ or more. Generally, experiments were divided into three titration periods of 10-15 min. This was long enough to obtain a precise measurement but short enough to obtain a linear proton secretion response. Systematically, at the end of each experiment, the saccule was removed from the titration chamber to check that the secreted protons were of biological origin. Then, 0.05 or $0.1 \mu$ equiv $\mathrm{HCl}$ was added as a standard to quantify $\mathrm{H}^{+}$excretion as nequiv $\mathrm{min}^{-1}$ otosac $^{-1}$.

\section{External $\mathrm{pH}$-dependence of proton secretion rate}

Fig. 1A illustrates a recording of a typical experiment showing the secretion of protons from one isolated saccule under different $\mathrm{pH}$ conditions. For each titration period, after the change of Ringer's solution, the apparatus was reset to fix the new $\mathrm{pH}$ end-point. This experiment shows that increasing the $\mathrm{pH}$ of the Ringer's solution immediately accelerated the rate of proton secretion, which returned to the initial rate when the $\mathrm{pH}$ was returned to that of the control period. In contrast (Fig. 1B), acidifying the Ringer's solution to $\mathrm{pH} 7.0-7.2$ completely stopped proton secretion. After a return to the initial $\mathrm{pH}$, proton secretion restarted after a short delay.

Fig. 2 presents the variations in the rates of proton secretion at various Ringer $\mathrm{pH}$ values ranging from 7.0 to 7.8 . The relationship is complex. Below pH 7.2, no proton secretion was detected, between 7.2 and 7.6, proton secretion increased rapidly; it continued to increase at more alkaline $\mathrm{pH}$ values, but slightly less rapidly. Fig. 2 also indicates that the results are similar irrespective of the buffer used (bicarbonate or Hepes). The hypothetical physiological significance of such a relationship for biocalcification will be discussed below.

Table 1. Ion concentrations, $\mathrm{pH}$, total $\mathrm{CO}_{2}$ and protein concentration of saccular endolymph and plasma in trout and turbot

\begin{tabular}{|c|c|c|c|c|}
\hline & \multicolumn{2}{|c|}{ Trout } & \multicolumn{2}{|c|}{ Turbot } \\
\hline & Plasma & Endolymph & Plasma & Endolymph \\
\hline$\left[\mathrm{Na}^{+}\right]\left(\mathrm{mmoll}^{-1}\right)$ & $174 \pm 8.4(7)$ & $90 \pm 3.4(9)^{*}$ & $165 \pm 4.4(15)$ & $117 \pm 4.3(13)^{*}$ \\
\hline$\left[\mathrm{K}^{+}\right]\left(\mathrm{mmoll}^{-1}\right)$ & $3.0 \pm 0.2(7)$ & $124 \pm 4.4(9) *$ & $3.4 \pm 0.2(15)$ & $69 \pm 2.7(9)^{*}$ \\
\hline$\left[\mathrm{Cl}^{-}\right]\left(\mathrm{mmoll}^{-1}\right)$ & $160 \pm 5.8(4)$ & $156 \pm 4.9(6)$ & $133 \pm 3.0(15)$ & $145 \pm 6.1(13)$ \\
\hline Total calcium $\left(\mathrm{mmoll}^{-1}\right)$ & $2.5 \pm 0.1(7)$ & $1.1 \pm 0.1(6)^{*}$ & $2.4 \pm 0.1(8)$ & $1.0 \pm 0.1(8)^{*}$ \\
\hline Total [phosphate] $\left(\mathrm{mmol}^{-1}\right)$ & $3.4 \pm 0.34(4)$ & $1.8 \pm 0.46(4) \dagger$ & $2.6 \pm 0,27(4)$ & $0.5 \pm 0.02(4)^{*}$ \\
\hline [Protein] $\left(\mathrm{g}^{-1}\right)$ & $34.2 \pm 1.02(7)$ & $2.1 \pm 0.0 .34(8)^{*}$ & $32.3 \pm 1.43(15)$ & $2.5 \pm 0.47(10)^{*}$ \\
\hline $\mathrm{pH}$ & $7.21 \pm 0.025(8)$ & $7.97 \pm 0.045(8)^{*}$ & & \\
\hline Total $\mathrm{CO}_{2}\left(\mathrm{mmoll}^{-1}\right)$ & $14.5 \pm 2.29(8)$ & $32.3 \pm 2.60(6)^{*}$ & $5.9 \pm 0.64(6)$ & $17.2 \pm 1.04(11)^{*}$ \\
\hline
\end{tabular}

Values are means \pm S.E.M. $(N)$.

Comparison between plasma and endolymph values: $\uparrow P<0.05$; $* P<0.001$; $t$-test. 


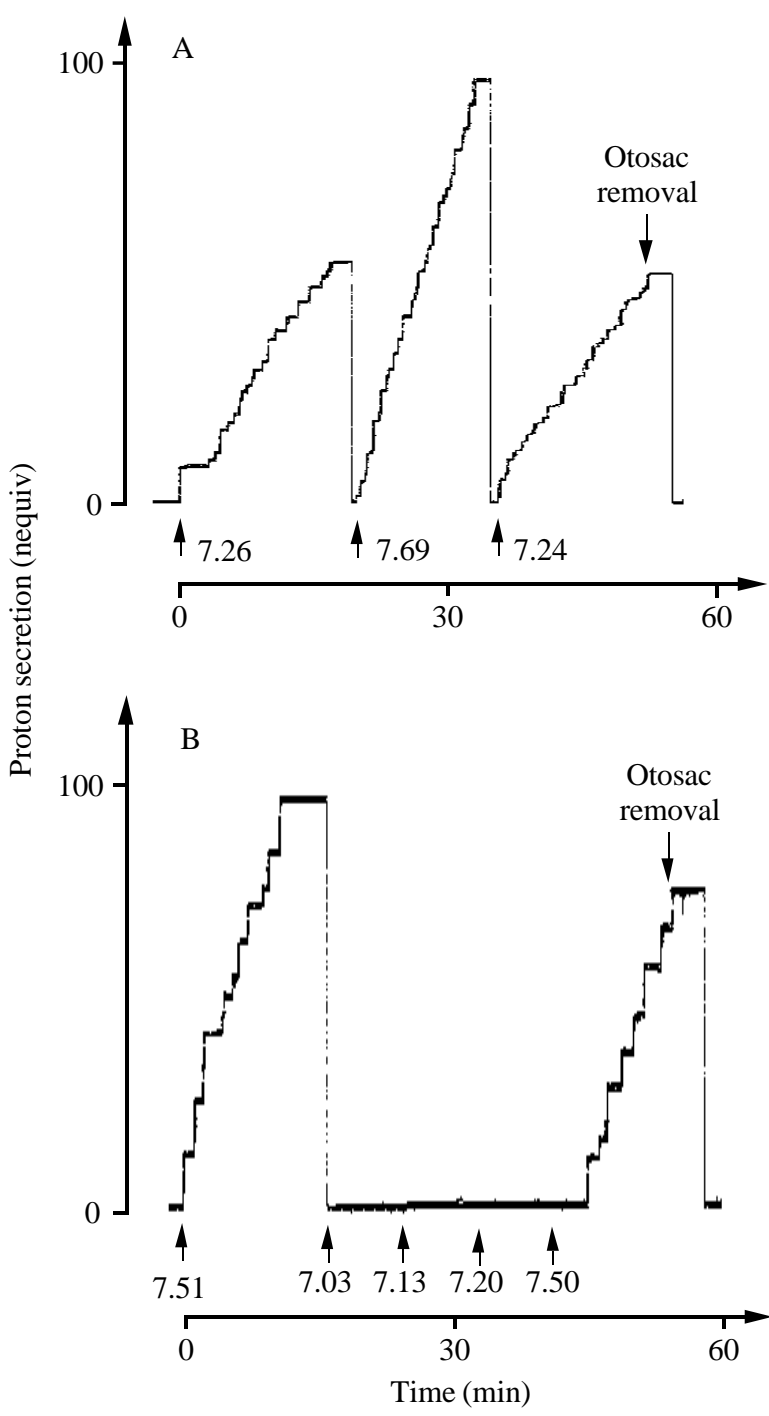

Fig. 1. Effect of the Ringer's solution $\mathrm{pH}$ on proton secretion by isolated saccular sacs. Experimental recordings of typical experiments. (A) Effect of increasing the $\mathrm{pH}$ of the Ringer's solution. (B) Effect of lowering the $\mathrm{pH}$ of the Ringer's solution. The arrows indicate the beginning of each period (after three successive rinsings with the new external medium). The $\mathrm{pH}$ of the solutions was held at different values indicated at the beginning of each period. Titrant was $1 \mathrm{mmol} \mathrm{l}^{-1} \mathrm{NaOH}$.

In order to concentrate the data, most of the following experiments were performed with an external $\mathrm{pH}$ of 7.4-7.6 using $1 \mathrm{mmoll}^{-1}$ bicarbonate-buffered Ringer's solution.

\section{$\mathrm{Na}^{+}$-gradient dependence of proton secretion rate}

The $\mathrm{Na}^{+}$gradient through the basal barrier of the saccular epithelium was reversed by using a $\mathrm{Na}^{+}$-free Ringer's solution. Fig. 3A shows a typical experiment in which $\mathrm{Na}^{+}$was substituted by an equivalent concentration of choline. The removal of $\mathrm{Na}^{+}$from the bathing medium caused a rapid and progressive inhibition of the rate of proton secretion which was complete within $20 \mathrm{~min}$. After returning to a normal Ringer's solution, proton secretion started again after an approximately

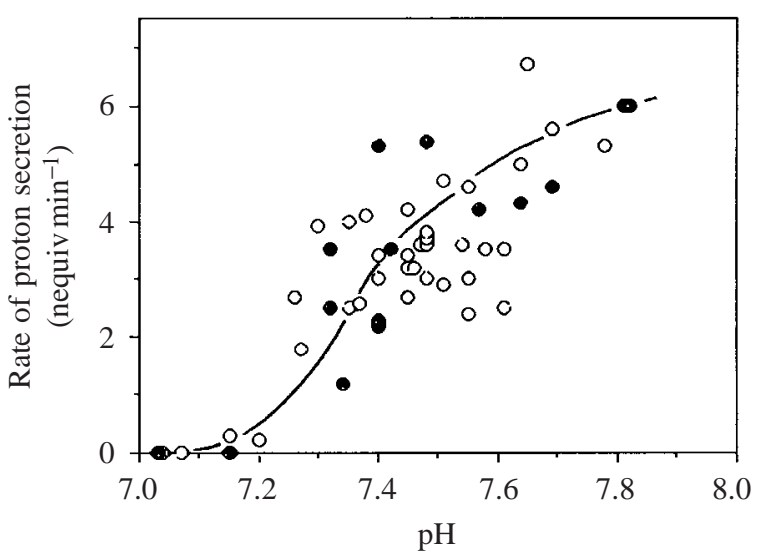

Fig. 2. Relationship between the rate of proton secretion by isolated saccular sacs and the $\mathrm{pH}$ of the Ringer's solution. Experiments were performed with Ringer's solutions containing $1 \mathrm{mmoll}^{-1}$ bicarbonate (open symbols) or $1 \mathrm{mmoll}^{-1}$ Hepes (filled symbols). The line was drawn by eye.

5 min lag. Fig. 3B summarizes experiments performed on seven saccules. To quantify the progressive inhibition, two successive periods of $5 \mathrm{~min}$ were selected to calculate proton secretion. Recovery was measured 3-5 min after the return to a normal Ringer's solution and led to a proton secretion rate not significantly different from that observed during the initial period. Thus, proton secretion is dependent on the presence of $\mathrm{Na}^{+}$on the basolateral side.

\section{Pharmacological characterization of proton secretion}

It was only possible to add drugs on the basolateral side of saccular epithelia. Preliminary experiments showed the importance of maintaining a well-aerated air-liquid interface in the titration chamber to allow saccules to excrete protons (results not shown). The addition of $1 \mathrm{mmoll}^{-1}$ cyanide (a mitochondrial inhibitor) completely inhibited proton secretion in a non-reversible manner (Fig. 4A). These results suggest that energy-dependent mechanisms are involved in proton secretion.

Ouabain $\left(1 \mathrm{mmoll}^{-1}\right)$, a common inhibitor of $\mathrm{Na}^{+} /$ $\mathrm{K}^{+}$ATPase, added to the normal Ringer's solution progressively inhibited the rate of proton secretion in a manner similar to that of a $\mathrm{Na}^{+}$-free Ringer's solution. However, unlike the inhibition caused by $\mathrm{Na}^{+}$-free Ringer, the inhibitory effect of ouabain was not significantly reversible within a 10 min period of recovery after rinsing out the inhibitor (Fig. 4B).

When amiloride, a diuretic inhibiting $\mathrm{Na}^{+}$transport and $\mathrm{Na}^{+} / \mathrm{H}^{+}$exchange, was used at concentration of $1 \mathrm{mmoll}^{-1}$, it immediately decreased the rate of proton secretion by up to $80 \%$. This inhibitory effect was partially reversible (Table 2 ).

Acetazolamide, a carbonic anhydrase inhibitor, which blocks the hydration of $\mathrm{CO}_{2}$ and consequently perturbs the acid-base balance of the cell, partially inhibits the secretion of protons in an irreversible manner when used at a concentration of $0.1 \mathrm{mmoll}^{-1}$ (Table 2). 

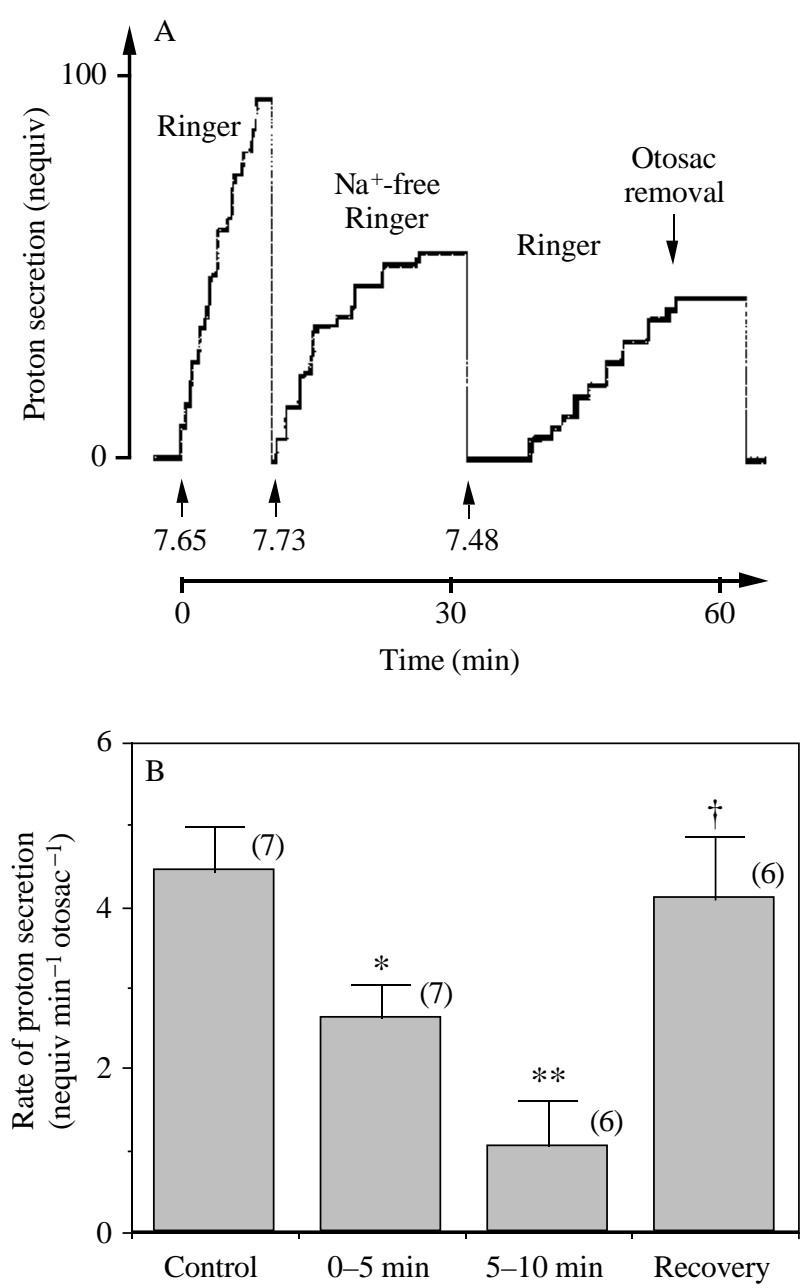

Fig. 3. Effect of $\mathrm{Na}^{+}$-free Ringer's solution on the rate of proton secretion by an isolated saccular sac. $\mathrm{Na}^{+}$was substituted with choline. (A) Experimental recording of a typical experiment. The $\mathrm{pH}$ of the solutions was held at different values indicated at the beginning of each period. Titrant was $1 \mathrm{mmoll}^{-1} \mathrm{KOH}$. (B) Rates of proton secretion in $\mathrm{Na}^{+}$-free Ringer's solution. Values are means + S.E.M. The number of experimental values is indicated in parentheses, and the $\mathrm{pH}$ of the solutions was held at the following values: 7.56 \pm 0.062 (control period); $7.56 \pm 0.081$ ( $0-5 \mathrm{~min}$ period); $7.57 \pm 0.081$ ( $5-10 \mathrm{~min}$ period) and $7.57 \pm 0.082$ (recovery period). Asterisks denote a significant difference from the rate in the control period; $* P<0.05$; $* * P<0.01$; $\dagger P<0.01$ compared to preceding period.

\section{Discussion}

\section{Ion distribution between plasma and endolymph}

Two fluids are in contact with the transporting cells of the saccular epithelium: cephalic fluid and blood. In fish, we think that the exchanges through the saccular epithelium occur preferentially with blood because the connective tissue surrounding the saccular epithelium is highly vascularized, forming a capillary bed (Mayer-Gostan et al. 1997). Furthermore, according to Enger (1964), cephalic fluid and plasma in teleosts do not show substantial differences in their ionic concentrations. Thus, comparisons of ionic distributions can reasonably be made between endolymph and plasma. Our

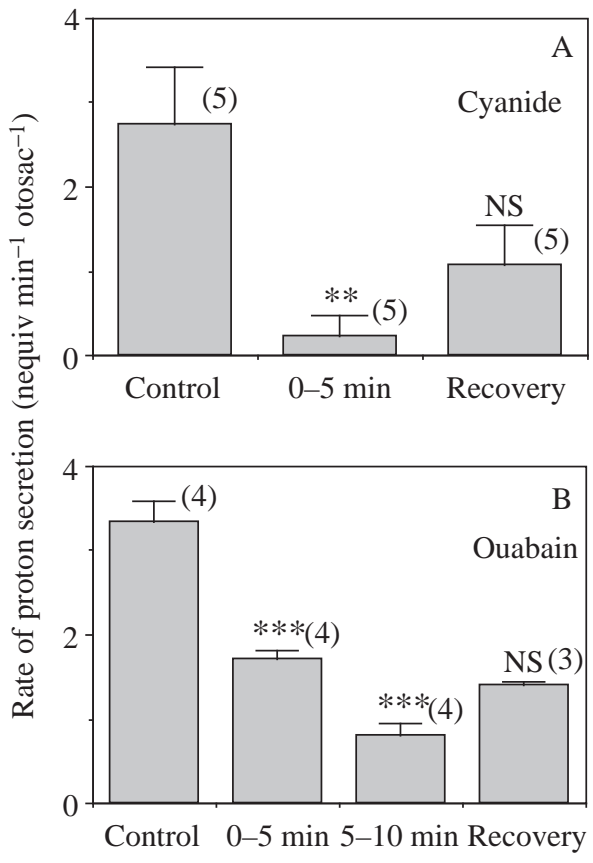

Fig. 4. Effect of $1 \mathrm{mmoll}^{-1}$ cyanide (A) and $1 \mathrm{mmoll}^{-1}$ ouabain (B) on the rate of proton secretion by isolated saccular sacs. Values are means + S.E.M. with the number of experiments given in parentheses. The $\mathrm{pH}$ of the solutions was held at the following values: (A) cyanide

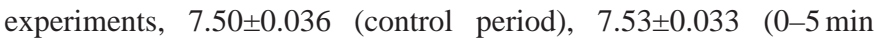
period), $7.51 \pm 0.043$ (recovery period); (B) ouabain experiments, $7.47 \pm 0.017$ (control period), 7.46 \pm 0.017 (0-5 min period), $7.46 \pm 0.017$ (5-10 min period) and $7.46 \pm 0.018$ (recovery period). Asterisks denote a significant difference from the rate in the control period; $* * P<0.01 ; * * * P<0.001$; NS, not significantly different from preceding period.

Table 2. Effect of amiloride and acetazolamide on proton secretion by isolated saccules of trout

\begin{tabular}{lcccc}
\hline & & \multicolumn{3}{c}{$\begin{array}{c}\text { Rate of proton secretion } \\
\text { (nequiv min }\end{array}$} \\
\cline { 3 - 5 } Drug & Ringer $\mathrm{pH}$ & Control & + Inhibitor & Recovery \\
\hline Amiloride & $7.54 \pm 0.042$ & $3.6 \pm 0.43$ & $0.8 \pm 0.44$ & $2.6 \pm 0.20$ \\
$\quad\left(1\right.$ mmol 1 $\left.^{-1}\right)$ & $(8)$ & $(8)$ & $(8)^{* *}$ & $(4) \dagger$ \\
Acetazolamide & $7.40 \pm 0.039$ & $3.7 \pm 0.27$ & $2.7 \pm 0.24$ & $2.71 \pm 0.26$ \\
$\left(0.1\right.$ mmol l$\left.^{-1}\right)$ & $(6)$ & $(6)$ & $(6)^{*}$ & $(4)$
\end{tabular}

Values are means \pm S.E.M. $(N)$.

Comparison between control and inhibited values, $* P<0.02$, $* * P<0.001$; comparison between inhibited and recovery values, $\dagger P<0.02$; $t$-tests.

results show that the differences in the ionic concentrations of plasma and endolymph are similar in the trout and turbot (Table 1) and are in agreement with previously published data. In the trout, the magnitude of the differences observed by Mugiya and Takahashi (1985) between plasma and endolymph concentrations was lower than that found in the present study. This is probably because our technical sampling procedure had 


\section{P. PAYAN AND OTHERS}

a low risk of contamination of the endolymph sample by body fluid. Kalish (1991) found a phosphate concentration of approximately $0.5 \mathrm{mmoll}^{-1}$ in the endolymph of the bearded rock cod Pseudophycis barbatus. This is the only measurement found in the literature and it is in the range of those found for turbot in the present study.

In vertebrates, the electrical potential of the endolymph side is always positive with respect to the perilymph, the voltage varying from $+80 \mathrm{mV}$ in the cochlea to $+5 \mathrm{mV}$ in the utriculus (Sterkers et al. 1988). The only published measurements in teleosts give a saccular potential of approximately $+10 \mathrm{mV}$ (Enger, 1964). The calculated Nernst potentials for $\mathrm{Na}^{+}$and $\mathrm{Cl}^{-}$in our study ranged from $+1 \mathrm{mV}$ to $+15 \mathrm{mV}$, values close to the potential measured by Enger (1964), suggesting passive $\mathrm{Na}^{+}$and $\mathrm{Cl}^{-}$distributions balanced by the transepithelial potential. The potential for $\mathrm{Ca}^{2+}$ cannot be calculated since some is bound to proteins. Mugiya and Takahashi (1985) suggested that endolymph $\mathrm{Ca}^{2+}$ is probably in equilibrium with the diffusible form of plasma $\mathrm{Ca}^{2+}$, although this does not necessarily mean that endolymph $\mathrm{Ca}^{2+}$ is not simply an ultrafiltrate of $\mathrm{Ca}^{2+}$ in the plasma.

The $\mathrm{K}^{+}$equilibrium potentials are approximately -92 to $-75 \mathrm{mV}$ in trout and turbot, respectively, values very different from the first recorded potential mentioned by Enger (1964). This suggests that energy-dependent mechanisms are involved in maintaining a high $\mathrm{K}^{+}$concentration in the endolymph. The nature of such a mechanism remains unknown. The very high $\mathrm{K}^{+}$concentration makes saccular endolymph unique among extracellular fluids and its functional significance may be related to electrophysiological events taking place in the macula, as has been recorded in mammals (Palmer, 1995; Sterkers et al. 1988).

Other features of the saccular endolymph are the high concentration of total $\mathrm{CO}_{2}$, with a resulting high alkalinity, as previously reported by Mugiya and Takahashi (1985). Thus, $\mathrm{H}^{+}$, like $\mathrm{K}^{+}$, is not in electrochemical equilibrium (equilibrium potential approximately $+50 \mathrm{mV}$ ). This means that energydependent mechanisms are involved in maintaining the $\mathrm{H}^{+}$ gradient between plasma and endolymph, which prompted us to investigate the nature of proton transport across the saccular epithelium.

\section{Kinetic characteristics of proton secretion by isolated saccules}

\section{Performances of the in vitro saccular sac preparation}

To measure the secretion of protons, we successively used the two saccules of each fish, the second being kept in situ and bathed in an aerated Ringer's solution before excision and use. They were taken at random, and the results were averaged because there was no significant difference between values for the left and right saccules. Several points are in favour of the in vitro technique for determining saccular proton secretion: the time the saccule remained active, the immediate termination of proton production following removal of the saccule, the reversibility of many effects $\left(\mathrm{Na}^{+}\right.$-free experiments, amiloride, $\mathrm{pH}$ ) and the effects of the well-known inhibitors used. Thus, the present work provides evidence that the in vitro saccular sac preparation is an adequate tool to study the mechanism of proton secretion.

\section{Hypothetical cellular model for proton secretion by the saccular epithelium}

An important advantage of using an isolated saccule mounted as a closed sac is that it reproduces in vivo conditions with regard to the electrochemical gradient across the saccular epithelium. Drugs can only be added to the basal side of the transporting epithelium. The main conclusions from the present study are summarized in Fig. 5, which proposes a hypothetical model of proton-transporting cells.

There are three main characteristics of proton secretion by the isolated saccular epithelium: metabolic energydependence, basolateral $\mathrm{Na}^{+}$-dependence and basolateral $\mathrm{pH}$ -

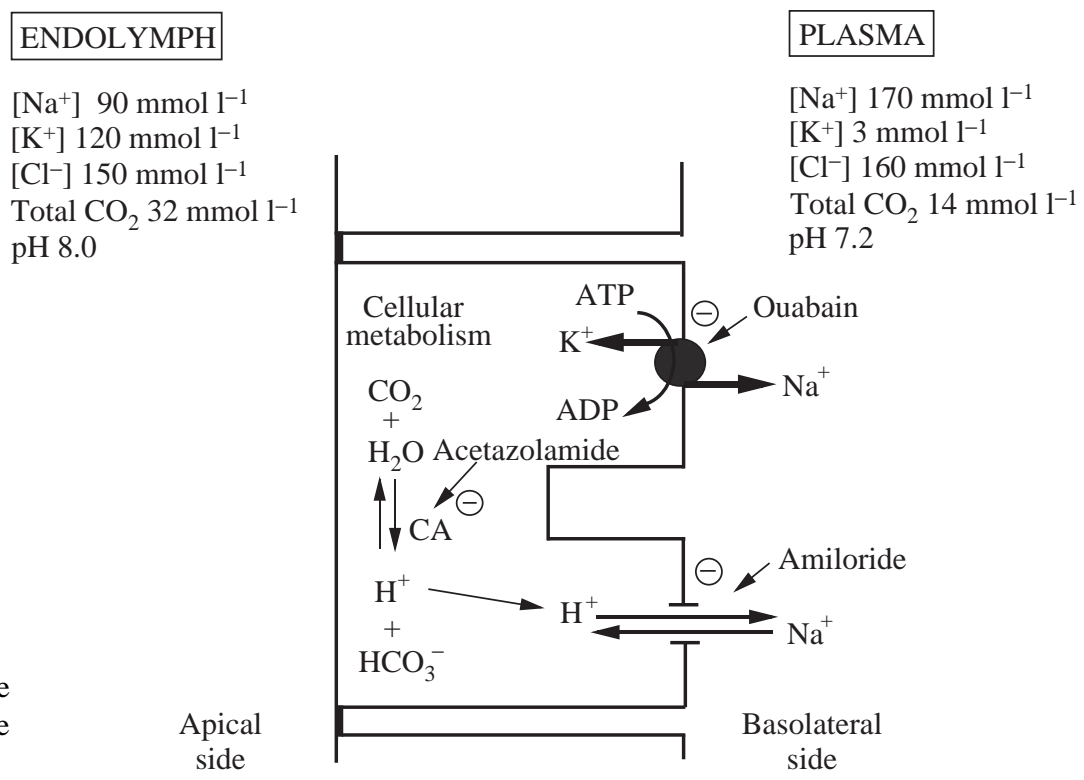

Fig. 5. Proposed model for cellular proton secretion by the saccular epithelium in trout Oncorhynchus mykiss (see Discussion). CA, carbonic anhydrase. side

side 
sensitivity. Proton secretion is driven via an energy-dependent mechanism (revealed by $\mathrm{KCN}$ and anaerobic experiments) involving a basolateral ouabain-sensitive $\mathrm{Na}^{+} / \mathrm{K}^{+}$-ATPase (see ouabain experiments). The importance of the presence of external $\mathrm{Na}^{+}$for proton secretion is indicated by the inhibitory effects of ouabain and amiloride and by the $\mathrm{Na}^{+}$-free experiments. Once the $\mathrm{Na}^{+}$pump had been exposed to ouabain, the progressive inhibitory effect on proton secretion probably resulted from a reduction of the $\mathrm{Na}^{+}$gradient and/or electrical potential across the basolateral barrier of the saccule. At $1 \mathrm{mmoll}^{-1}$, amiloride, acting as a competitive agent, immediately blocks $\mathrm{Na}^{+}$conductance and $\mathrm{Na}^{+} / \mathrm{H}^{+}$exchange in most transporting epithelia (Turnheim, 1994). Thus, a Na $\mathrm{Na}^{+}$ exchanger is probably located at the basolateral barrier of the epithelium; the occurrence of $\mathrm{Na}^{+}$conductance is more speculative. The observation that removal of $\mathrm{Na}^{+}$did not immediately inhibit $\mathrm{H}^{+}$release (Fig. 3) is more difficult to interpret. One possibility is that the connective tissue, with a thickness of 40-70 $\mathrm{m}$ (Mayer-Gostan et al. 1997), could maintain a small pool of $\mathrm{Na}^{+}$near the basal membrane of the saccular epithelium.

The alkalinity of endolymph compared with that of the plasma, which is characteristic of fish, may originate in two ways: from a net transepithelial transport of $\mathrm{HCO}_{3}{ }^{-}$from plasma to endolymph and/or from $\mathrm{CO}_{2}$. In our experimental conditions, the first possibility may be discarded as the presence of $\mathrm{HCO}_{3}{ }^{-}$in the Ringer's solution was not essential to proton secretion (Fig. 2). The contribution of external $\mathrm{CO}_{2}$ as a source of protons by diffusion into epithelial cells and conversion into $\mathrm{H}^{+}+\mathrm{HCO}_{3}{ }^{-}$, even if it occurs, must be very minor as the Ringer's solution was equilibrated with air (only $0.03 \% \mathrm{CO}_{2}$ gas). Although these external plasma sources may be present in vivo, we propose that, in our in vitro experimental conditions at any rate, excreted protons must have originated from cellular metabolism. The requirement for glucose in the Ringer's solution and the inhibitory effect of acetazolamide support this hypothesis. This proposition is in agreement with the results of Mugiya et al. (1979), who measured carbonic anhydrase activity in the trout saccule, and Mayer-Gostan et al. (1997), who detected carbonic anhydrase using immunohistology in ionocytes from the saccule.

From these considerations, it appears that the epithelial cells of the trout saccule share numerous functional similarities with the $\alpha$-cells involved in urine acidification in the proximal tubules of mammalian nephrons (Gluck and Nelson, 1992). The apical membranes of these cells, which are in contact with the urine, correspond to the basal sides of saccular cells. Experiments are now in progress to identitfy the cells responsible for ionic transfer across the saccular wall.

\section{The importance of the plasma $\mathrm{pH}$-dependence of saccular proton secretion}

Numerous studies have emphasized the importance of acid-base equilibrium in otolith calcium deposition. Among the most relevant, Mugiya and Takahashi (1985) described diurnal variations of $\mathrm{pH}$ and total $\mathrm{CO}_{2}$ in both plasma and endolymph of the trout, Erulkar and Maren (1961) found that the inner ear of cats contained a very high activity of carbonic anhydrase and Mugiya et al. (1979) noted the importance of this enzyme in otolith formation in trout. In view of the role of carbonic anhydrase, Gauldie and Nelson (1990) suggested the importance of a $\mathrm{pH}$ gradient in the endolymph for the calcification of the otolith. All these conclusions emphasize the importance of endolymph acid-base balance and especially of the $\mathrm{pH}$. The present in vitro results clearly demonstrate that the $\mathrm{pH}$ of the Ringer's solution modulates saccular proton secretion and most probably also endolymph $\mathrm{pH}$. Thus, we propose a cellular mechanism to explain the correlation described by Mugiya and Takahashi (1985) between serum and endolymph $\mathrm{pH}$ during a $24 \mathrm{~h}$ cycle. According to our results, in the physiological range of plasma $\mathrm{pH}$, a change of $0.2 \mathrm{pH}$ units in the Ringer's solution could induce a change (of up to twofold) in the rate of proton secretion (Fig. 2).

In view of this, an approximate calculation of endolymph total $\mathrm{CO}_{2}$ turnover in the trout is of interest. Taking into account the proton secretion rate at $\mathrm{pH} 7.4$ in Ringer's solution (3-4 nequiv min $^{-1}$ otosac $^{-1}$, Fig. 2), and the pool of total $\mathrm{CO}_{2}$ in the endolymph of an individual saccule (the product of the concentration, $32 \mathrm{mmoll}^{-1}$, and the endolymph volume, approximately $10 \mu \mathrm{l}$ ), the turnover of total $\mathrm{CO}_{2}$ was found to be approximately $60 \% \mathrm{~h}^{-1}$. This is an extremely high exchange rate which supports the hypothesis of a relationship between endolymph $\mathrm{pH}$ and plasma $\mathrm{pH}$ via the rate of proton secretion by the saccule. Thus, in addition to a direct, passive effect via an increase in the total plasma $\mathrm{CO}_{2}$ content observed during light photoperiods by Mugiya and Takahashi (1985), we propose a further effect involving a $\mathrm{pH}$-dependent proton secretory mechanism.

To our knowledge, the presence of a $\mathrm{pH}$ gradient in the inner ear of teleosts is unique among the vertebrates and is probably related to biocalcification of otoliths, as $\mathrm{pH}$ has been suggested as the major factor affecting the rate of calcium deposition in this organ (Gauldie and Nelson, 1990; Gauldie et al. 1995). The trout saccule, which can be easily isolated and mounted as a sac, offers a good tool for comparative physiological research as it provides a model for studying exchange mechanisms and their regulation that is common to the inner ears of all vertebrates.

This research was supported by IFREMER (programme Régulation de la croissance chez les poissons). H.K. was the recipient of a grant from the Ministère des Affaires Etrangères (programmes ECOS CONICYT de coopération scientifique entre la France et le Chili, C93BO9). We are indebted to Mrs B. Maetz for revising the manuscript.

\section{References}

Campana, S. E. And Neilson, J. D. (1985). Microstructure of fish otoliths. Can. J. Fish. aquat. Sci. 42, 1014-1032.

DALE, T. (1980). Surface morphology of the acoustico-lateralis sensory organ in teleosts: functional and evolutionary aspects. In 


\section{P. PAYAN AND OTHERS}

Environmental Physiology of Fishes (ed. M. A. Ali), pp. 387-402. New York, London: Plenum Press.

ENGER, P. R. (1964). Ionic composition of the cranial and labyrinthine fluids and saccular D.C. potentials in fish. Comp. Biochem. Physiol. 11, 131-137.

Erulkar, S. AND Maren, T. H. (1961). Carbonic anhydrase and the inner ear. Nature 189, 549-460.

FANGE, R., LARSSON, A. AND LidMAn, U. (1972). Fluids and jellies of the acousticolateralis system in relation to body fluids in Coryphaenoides rupestris and other fishes. Mar. Biol. 17, 180-185.

Gauldie, R. W. And Nelson, D. G. A. (1990). Otolith growth in fishes. Comp. Biochem. Physiol. 97A, 119-135.

Gauldie, R. W., West, I. F. AND CoOte, G. E. (1995). Evaluating otolith age estimates for Hoplostethus atlanticus by comparing patterns of checks, cycle in microincrement width and cycles in strontium and calcium composition. Bull. mar. Sci. 56, 76-102.

Gluck, S. AND Nelson, R. (1992). The role of V-ATPase in renal epithelial $\mathrm{H}^{+}$transport. J. exp. Biol. 172, 205-218.

JONES, C. M. (1992). Otolithic microstructure examination and analysis. Can. spec. Publ. Fish. aquat. Sci. 74, 137-159.

KaLish, J. M. (1991). Determinants of otolith chemistry: seasonal variation in the composition of blood plasma, endolymph and otoliths of bearded rock cod Pseudophycis barbatus. Mar. Ecol. Prog. Ser. 74, 137-159.
Lowenstein, O. (1971). The labyrinth. In Fish Physiology, vol. 5 (ed. W. S. Hoar and D. J. Randall), pp. 207-240. London: Academic Press.

Mayer-Gostan, N., Kossman, H., Watrin, A., Payan, P. And Boeuf, G. (1997). Distribution of ionocytes in the saccular epithelium of the inner ear of two teleosts Oncorhynchus mykiss and Scophtalmus maximus. Cell Tissue Res. (in press).

MugiYa, Y., Kawamurah, H. and Aratsu, S. (1979). Carbonic anhydrase and otolith formation in the rainbow trout, Salmo gairdneri: enzyme activity of the sacculus and calcium uptake by the otolith in vitro. Bull. Jap. Soc. sci. Fish. 45, 879-882.

MugiYa, Y. AND TAKAHASHI, T. (1985). Chemical properties of the saccular endolymph in the rainbow trout, Salmo gairdneri. Bull. Fac. Fish. Hokkaido Univ. 36, 57-63.

Palmer, L. G. (1995). Epithelial Na channels and their kin. News physiol. Sci. 10, 61-67.

Panella, G. (1971). Fish otoliths: Daily growth layers and periodical patterns. Science 173, 1124-1127.

Sterkers, O., Ferrary, E. AND Amiel, C. (1988). Production of inner ear fluids. Physiol. Rev. 68, 1083-1128.

TurnheIM, K. (1994). Epithelial sodium transport: basic autoregulatory mechanisms. Physiol. Res. 43, 211-218.

Watanabe, Y. And Miyamoto, H. (1973). Biochemistry study of labyrinthine fluids of the fish. Med. J. Osaka Univ. 23, 273-282. 